\title{
Correlation between blood group type and Catheter- associated urinary tract infections (CA-UTI) in critically ill patients: A Retrospective Cohort Study
}

Khalid Al Sulaiman ( $\square$ alsulaimankh@hotmail.com )

King Abdulaziz Medical City https://orcid.org/0000-0002-5547-2043

Nouf Al Qahtani

King Abdulaziz Medical City

Mashael Al Muqrin

King Abdulaziz Medical City

Maram Al Dossari

King Abdulaziz Medical City

Ali Al Wabel

Qassim University College of Pharmacy

Tareq Al Sulaiman

Imam Abdulrahman Al Faisal Hospital

\section{Ramesh Vishwakarma}

King Abdullah International Medical Research Center

\section{Research article}

Keywords: Critically ill, Blood group types, 0 group type, Urinary Tract infection (UTI), Catheter-associated urinary tract infections (CA-UTI), Intensive Care Unit (ICU)

Posted Date: November 2nd, 2020

DOI: https://doi.org/10.21203/rs.3.rs-78799/v1

License: (1) (i) This work is licensed under a Creative Commons Attribution 4.0 International License. Read Full License 


\section{Abstract}

Background: CA-UTI consider one of the most common hospital acquired infections. Several risk factors for CA-UTI have been identified. There is no enough evidence regard the impact of ABO type and the risk of CA-UTI acquisition. The aim of this study is to investigate the correlation between $A B O$ types and the risk of having recurrent, reinfection CA-UTI, and MDR reinfection in critically ill.

Methodology: A retrospective cohort study of adult ICU patients through 2018 in ICU at tertiary hospital who have confirmed CA-UTI to investigate the correlation between ABO type with the susceptibility of recurrent, reinfection and MDR reinfection CA-UTI in critically ill. 1730 patients were reviewed to screen patients for inclusion into the study,203 patients have confirmed CA-UTI using 2010 IDSA guideline definition.81 patients meeting inclusion/exclusion criteria were enrolled. Patients were divided into two groups based on ABO type (O-group Vs. Non-O group). We considered a P value of $<0.05$ as statistically significant.

Results: Among 81 patients, 37 patients (45.6\%) had O blood group type. Patients with 0 blood group type were associated with lower rate of recurrent CA-UTI (OR 0.28, 95\% $\mathrm{Cl} 0.085-0.952, \mathrm{P}=0.0414)$, multidrug resistant (MDR) organisms (OR 0.05, 95\% Cl 0.003-0.752, $\mathrm{P}=0.0304)$, shorter ICU LOS (Est (SE): -0.024 (0.045), $\mathrm{P}=<0.001$ ) and mechanical ventilation duration (Est. (SE): $-0.41(0.066), \mathrm{P}=<0.001$ ) compared with non-O blood group type. On the other hand, neither CA-UTI reinfection (OR 1.47, 95\% Cl $0.357-6.054, \mathrm{P}=0.5538)$ nor ICU mortality (OR $0.70,95 \% \mathrm{Cl} 0.219-2.257, \mathrm{P}=0.5538)$ were statistically significant.

Conclusion: Patients with non-O group type were statistically significant associated with higher rate of recurrent CA-UTI and MDRO. These data confirm the need for randomized controlled trials with a larger sample size to clarify and confirm our study findings.

\section{Introduction:}

Catheter-associated urinary tract infections (CA-UTI) consider as one of the most common hospitalsacquired infections (Lo E et al. 2014). The Infectious Diseases Society of America (IDSA) guidelines define asymptomatic CA-UTI as a culture growth of $\geq 100,000 \mathrm{CFU} / \mathrm{ML}$ of uropathogenic bacteria in asymptomatic patients with urinary catheterization (e.g. indwelling urethral, indwelling suprapubic, or intermittent catheterization). While symptomatic CA-UTI is defined by IDSA as culture growth of $\geq$ $10,000 \mathrm{CFU} / \mathrm{ML}$ of uropathogenic bacteria in the presence of symptoms or signs compatible with UTI (Hooton et al. 2010).

Up to $80 \%$ of hospital acquired urinary tract infections are attributable to urinary catheterization (Weber DJ et. al 2011). The daily risk of acquisition bacteriuria secondary to urinary catheterization varies from $3 \%-7 \%$ (Lo E et al. 2014). Of those with bacteriuria, up to $25 \%$ become symptomatic (Leuck AM et. al 2012). Escherichia coli and Candida species are the most common prevalent organisms causing CA-UTI, 
followed by Enterococcus species, Pseudomonas species, Klebsiella species \& Staphylococcus aureus (Puri J et al. 2002, Weiner LM. et al. 2016).

Several risk factors for CA-UTI acquisition have been identified, catheterization duration is one of the most important risk factors. Other risk factors include old age, female gender, colonization of the drainage bag with bacteria, and/or diabetes mellitus (Kunin CM. et al. 1966, Platt R. et al. 1986). CA-UTI is associated with several complications such as bacteremia, sepsis and/or involvement of the upper urinary tract (Gould CV. et al. 2009, Warren JW. et al. 1988). Several studies show that CA-UTI is associated with increased mortality rates and prolonged length of stay (LOS) (Nicolle. et al. 2014, Chant C. et al. 2011).

There are many blood group systems have been identified and characterized. However, ABO system is still the most clinically significant in many practices like organ transplantation medicine and blood transfusion (Sigmon, J.M et. al 1992). The surfaces of red blood cells (RBCs) have carbohydrate molecules that have roles in membrane transportation of molecules, acting as receptors for extracellular ligands and enzymes, cell membrane integrity and cell adhesion. $A B O$ antigens are found having similar roles on epithelial cells as well as red blood cells (Reid, M.E. et. al 2004, Mohandas, N. et al. 2005)

The relation between $\mathrm{ABO}$ blood group and the susceptibility to certain infectious diseases is well recognized (Kinane, D.F. et al. 1982, Peter d'adamo. et al. 2015, Annette epp. et al. 2010). Adherence to solid substrates is a property common to many pathogenic microorganisms, including viruses, bacteria, yeasts, and protozoa, by attaching to host structures which considered a necessary as it's the first step in the colonization of host mucosal surfaces, microbial pathogens avoid being swept along by the normal flow of body fluids (blood, urine, intestinal contents) and eliminated which can lead to invasive infection in many situations (Hooton et al. 2010, Johnson, J.R. et al. 1991, Schoolnik, G.K. et al. 1989 m Stapleton, A. et al. 1992).

ABO blood group system extends beyond transfusion medicine. Antigens on the extracellular surface of RBC membranes may influencing the susceptibility to several different pathogens (Liumbruno GM. et al. 2013). There is no enough evidence regarding the impact of blood group type and the risk of CA-UTI acquisition. The aim of this is to investigate the correlation between blood group type (O-group Vs. Non-O group) and the risk of having recurrent CA-UTI, CA-UTI reinfection and MDR reinfection in critically ill patients with indwelling urinary catheter.

\section{Methods:}

\section{Study design}

A retrospective cohort study of adult ICU patients over 12 months period in intensive care units at tertiary hospital who have confirmed Catheter-associated urinary tract infections (CA-UTI) between January 1st, 2018 to December 31st, 2018 to investigate the correlation between blood group type with recurrent, reinfection and MDR reinfection CA-UTI in critically ill patients with CA-UTI. Secondary endpoints to 
determine ICU mortality, ICU length of stay and the most common blood group type with high susceptibility to CA-UTI in Saudi populations. A total of 1730 patients were reviewed to screen patients for inclusion into the study, 203 patients have confirmed CA-UTI using IDSA guideline definition (Hooton et al. 2010). Among the 203 patients, 81 patients meeting inclusion/exclusion criteria were enrolled. Patients were divided into two groups based on blood group type (O-group Vs. Non-O group).

Generally, urinary catheterization with latex rubber was used. While, for patients with a latex allergy or who expected to stay on a urinary catheter for a long time, urinary catheterization with silicone was utilized. The study was approved in May 2019 by King Abdullah International Medical Research Center Institutional Review Board, Riyadh, Saudi Arabia.

\section{Setting}

This study was conducted in the adult ICUs (i.e. medical, surgical, trauma and burn ICUs) at King AbdulAziz Medical City (KAMC) - National Guard Health Affairs (NGHA), a tertiary- care academic referral hospital in Riyadh, Saudi Arabia. The ICU admits medical, surgical, trauma, burn patients, and operates as a closed unit with $24 / 7$ onsite coverage by critical care board-certified intensivists. The nurse-to-patient ratio in the unit is approximately 1:1.2. In addition, clinical pharmacists' specialist is a part of the daily multidisciplinary rounds (Al Sulaiman K. et al. 2020).

\section{Data collection}

Demographic and clinical data including age, gender, weight, body mass index, associated comorbidities, laboratory baseline including but not limited to $A B O$ and rhesus blood group type, urine output (UOP), and renal function within 24 hours of ICU admission. Additionally, Glasgow Coma Scale (GCS), Acute Physiology and Chronic Health Evaluation (APACHE II) score, Sequential Organ Failure Assessment (SOFA) score, and Nutrition Risk in Critically ill (NUTRIC) score were recorded for eligible patients on the first day. Moreover, urinary culture (s), recurrent, reinfection and MDR reinfection CA-UTI, antibiotics dosing and duration, ICU admission date, ICU discharge date, ICU mortality with 30 days, mechanical ventilation duration and history of admission, surgery or dialysis within 3 months of ICU admission were reviewed and recorded. CA-UTI reinfection is defined as UTI occurring more than 14 days after the original CA-UTI. While recurrence CA-UTI is defined as infection by an organism different from that in the preceding infection.

\section{Eligibility criteria}

Patients were enrolled in the study if they were critically ill patients aged $\geq 16 \mathrm{y} / \mathrm{o}$ with known $A B O$ group type and confirmed Catheter-associated urinary tract infections (CA-UTI) within ICU admission. Exclusion criteria included using immunosuppression medication(s)/ immunocompromised patient, inappropriate antibiotic (s) dosing and duration within 72 hours of positive culture (using Micromedex $\circledast$ database), previous admission or antibiotic use within 3 months of admission, repeated urinary catheter culture within 3 days is negative without any new addition of antibiotic (s). Also, patients with sampling from the 
catheter collection system (e.g., catheter bag), urine culture $<100000$ CFU/MLS, or more than two species of microorganism isolated were excluded.

\section{Outcomes}

The primary outcome is to investigate the correlation between 0-group types ( $0+\&$ O-) Vs. Non-O group types (A+, A-, B+, B-, AB+, AB-) and CA-UTI. In addition, the correlation of O-group types Vs. Non-O group types with the risk of having recurrent CA-UTI, CA-UTI reinfection and MDR reinfection in critically ill patients. Secondary outcomes were to determine the most common blood group type with high susceptibility to CA-UTI in critically ill patients, ICU length of stay (LOS), hospital LOS, Mechanical Ventilation (MV) duration and ICU mortality.

\section{Data management and Statistical analysis}

Collected data were entered in Microsoft Excel 2010 after being coded. There were two arms considered in this study, patients' O-group types Vs. Non-O group type. Multivariate binary and multinomial logistic regression were used to find out the relationship between blood groups and different outcomes considered in this study, adjusting for patients' body mass index (BMI), Baseline APACHE II severity score, Acute Kidney Injury status within 24 hours of ICU admission, and status of previous surgery and/or dialysis with 3 months.

We summarized categorical variables as number (percentage) and numerical variables (continuous variables) as mean and standard deviation (SD). The normality assumptions were assessed for all numerical variables using statistical test (i.e. Shapiro-Wilk test) and using graphical representation (i.e. histograms and Q-Q plots). We compared categorical variables using the chi-square or Fisher exact test, normally distributed numerical variables with the t-test, and other quantitative variables with the MannWhitney $U$ test. Baseline characteristics, baseline severity and outcome variables were compared between the two groups.

Generalized linear regression was also used to find out the relationship between blood groups and the different outcomes considered in this study, adjusting for the same prognostic factors as used for logistic regressions. The odds ratios (OR) and estimates with the $95 \%$ confidence intervals $(\mathrm{Cl})$ were reported for the associations. We considered a $\mathrm{P}$ value of $<0.05$ statistically significant and used SAS version 9.4 for all statistical analyses.

\section{Results:}

\section{Patient characteristics}

Among 1730 patients screened with documented $A B O$ group type (91.50\% RhD positive), 203 patients have confirmed CA-UTI (91.62\% RhD positive). The study included 81 patients, of which $37(45.6 \%)$ had 0 blood group and 44 patients (54.3\%) were from Non-O blood group. In non- 0 blood group, most patients were $A+22(50.0 \%)$ followed by $B+15(34.1 \%)$. Table 1 depicts the baseline and clinical characteristics 
of $\mathrm{O}$ and non-O blood group patients. Most of the baseline and clinical characteristics were found to be very similar between the two groups. Albumin was significantly high in patients with 0 blood group as compared to non-O blood groups $(P=0.0223)$. 
Table 1

Baseline and clinical characteristics between $\mathrm{O}$ and Non-O groups.

\begin{tabular}{|c|c|c|c|}
\hline Parameters & $\begin{array}{l}0 \text { group } \\
(N=37)\end{array}$ & $\begin{array}{l}\text { Non-0 group } \\
(\mathrm{N}=44)\end{array}$ & p-value \\
\hline Age (years), Mean (SD) & $62.05(18.69)$ & $65.30(19.39)$ & $0.4484^{*}$ \\
\hline Body mass index (BMI), Mean (SD) & $30.14(6.47)$ & $29.75(8.90)$ & $0.8254^{\star}$ \\
\hline Gender, n (\%) & & & $0.3108^{\wedge \wedge}$ \\
\hline Female & $16(43.2)$ & $24(54.5)$ & \\
\hline Male & $21(56.8)$ & $20(45.5)$ & \\
\hline Rhesus Rh factor, n (\%) & & & $0.3689 * *$ \\
\hline Positive & $36(97.3)$ & $40(90.9)$ & \\
\hline Negative & $1(2.7)$ & $4(9.1)$ & \\
\hline \multicolumn{4}{|l|}{ Co-morbidities } \\
\hline Hypertension (HTN), n (\%) & $21(56.8)$ & $28(63.6)$ & $0.5281^{\wedge \wedge}$ \\
\hline Dyslipidemia (DLP), n (\%) & $6(16.2)$ & $7(15.9)$ & $0.9701^{\wedge \wedge}$ \\
\hline Diabetes (DM), n (\%) & $25(67.6)$ & $24(54.5)$ & $0.2324^{\wedge \wedge}$ \\
\hline Acute Coronary Syndrome (ACS), n (\%) & $0(0.0)$ & $1(2.3)$ & $>0.9999 * *$ \\
\hline $\begin{array}{l}\text { Acute Kidney Injury status within } 24 \text { hours of ICU } \\
\text { admission, } \mathrm{n}(\%)\end{array}$ & $10(27.0)$ & $14(31.8)$ & $0.0638^{\wedge \wedge}$ \\
\hline Asthma, n (\%) & $1(2.7)$ & $2(4.5)$ & 0.9999** \\
\hline $\begin{array}{l}\text { Chronic obstructive pulmonary disease (COPD), } \mathrm{n} \\
(\%)\end{array}$ & $3(8.1)$ & $3(6.8)$ & 0.9999** \\
\hline Ischemic Stroke, n (\%) & $9(24.3)$ & $6(13.6)$ & $0.2174^{\wedge \wedge}$ \\
\hline Cancer, n (\%) & $2(5.4)$ & $4(9.1)$ & $0.6829 * *$ \\
\hline Chronic kidney disease (CKD), n (\%) & $8(21.6)$ & $10(22.7)$ & $0.9051^{\wedge \wedge}$ \\
\hline Ischemic heart disease (IHD), n (\%) & $5(13.5)$ & $8(18.2)$ & $0.5686^{\wedge \wedge}$ \\
\hline \multicolumn{4}{|c|}{-Denominator of the percentage is the total number of patients } \\
\hline \multicolumn{4}{|c|}{ *T -Test / ^ Wilcoxon rank sum test is used to calculate the P-value. } \\
\hline 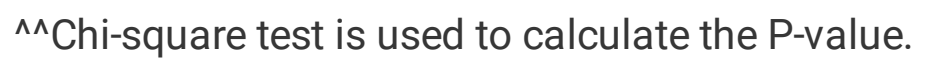 & & & \\
\hline
\end{tabular}




\begin{tabular}{|c|c|c|c|}
\hline Parameters & $\begin{array}{l}0 \text { group } \\
(N=37)\end{array}$ & $\begin{array}{l}\text { Non-0 group } \\
(N=44)\end{array}$ & p-value \\
\hline Coronary artery bypass grafting (CABG), $\mathrm{n}(\%)$ & $0(0.0)$ & $3(6.8)$ & $0.2463^{\star *}$ \\
\hline Percutaneous coronary intervention (PCI), n (\%) & $0(0.0)$ & $4(9.1)$ & $0.1213^{\star *}$ \\
\hline Dialysis during ICU stay, n (\%) & $10(27.0)$ & $9(20.5)$ & $0.4868^{\wedge \wedge}$ \\
\hline Heart failure (HF), n (\%) & $6(16.2)$ & $5(11.4)$ & $0.5254^{\wedge \wedge}$ \\
\hline Hypothyroidism, n (\%) & $1(2.7)$ & $4(9.1)$ & $0.3689 * *$ \\
\hline Liver disease (any type), n (\%) & $7(18.9)$ & $4(9.1)$ & $0.1984^{\wedge \wedge}$ \\
\hline \multicolumn{4}{|l|}{ Baseline (Within 24 hours of ICU admission) } \\
\hline Serum sodium (Na), Median (Q1,Q3) & $\begin{array}{l}\text { 138.00( } \\
133.00 \\
141.00)\end{array}$ & $\begin{array}{l}\text { 137.42( } \\
135.00 \\
139.13)\end{array}$ & $0.9583^{\wedge}$ \\
\hline Serum potassium (K), Mean (SD) & $4.29(0.55)$ & $4.16(0.74)$ & $0.3713^{\star}$ \\
\hline Serum Bicarbonate (CO2), Median (Q1,Q3) & $\begin{array}{l}19.00(17.00 \\
21.00)\end{array}$ & $\begin{array}{l}21.00(18.00 \\
24.00)\end{array}$ & $0.0704^{\wedge}$ \\
\hline Serum Chloride (CL), Median (Q1,Q3) & $\begin{array}{l}105.00( \\
100.00 \\
110.00)\end{array}$ & $\begin{array}{l}\text { 104.50( } \\
100.00 \\
108.75)\end{array}$ & $0.5688^{\wedge}$ \\
\hline ALT, Median (Q1,Q3) & $\begin{array}{l}33.00(13.00 \\
66.00)\end{array}$ & $\begin{array}{l}21.00(14.00 \\
33.00)\end{array}$ & $0.2527^{\wedge}$ \\
\hline AST, Median (Q1,Q3) & $\begin{array}{l}51.00(27.00 \\
81.00)\end{array}$ & $\begin{array}{l}31.00(23.00 \\
63.00)\end{array}$ & $0.1982^{\wedge}$ \\
\hline Total Bilirubin $(\mu \mathrm{mol} / \mathrm{L})$, Median $(\mathrm{Q} 1, \mathrm{Q} 3)$ & $\begin{array}{l}14.20(8.70 \\
30.60)\end{array}$ & $\begin{array}{l}14.10(10.40 \\
24.60)\end{array}$ & $0.7762^{\wedge}$ \\
\hline Albumin (g/L), Mean (SD) & $30.25(4.80)$ & $27.53(5.41)$ & $0.0223^{\star}$ \\
\hline GCS baseline, Median (Q1,Q3) & $\begin{array}{l}12.00(8.00 \\
15.00)\end{array}$ & $\begin{array}{l}11.00(6.00 \\
14.50)\end{array}$ & $0.2761^{\wedge}$ \\
\hline Blood glucose level (mmol/l), Median (Q1,Q3) & $\begin{array}{l}13.30(8.70 \\
17.55)\end{array}$ & $\begin{array}{l}12.05 \text { ( } 8.05 \\
16.45)\end{array}$ & $0.4892^{\wedge}$ \\
\hline
\end{tabular}

-Denominator of the percentage is the total number of patients

${ }^{\star} T$-Test / ^ Wilcoxon rank sum test is used to calculate the P-value.

${ }^{\wedge}{ }^{\wedge}$ Chi-square test is used to calculate the P-value.

**Fisher Exact test is used to calculate the P-value. 


\begin{tabular}{|c|c|c|c|}
\hline Parameters & $\begin{array}{l}0 \text { group } \\
(N=37)\end{array}$ & $\begin{array}{l}\text { Non-0 group } \\
(\mathrm{N}=44)\end{array}$ & p-value \\
\hline Hematocrit (HCT), Median (Q1,Q3) & $\begin{array}{l}0.33(0.29 \\
0.40)\end{array}$ & $\begin{array}{l}0.33(0.26 \\
0.37)\end{array}$ & $0.5692^{\wedge}$ \\
\hline Lactic acid, Median (Q1,Q3) & $\begin{array}{l}1.96(1.46 \\
3.10)\end{array}$ & $\begin{array}{l}1.71(1.21 \\
3.07)\end{array}$ & $0.8203^{\wedge}$ \\
\hline Lowest MAP, Median (Q1,Q3) & $\begin{array}{l}65.00(60.00 \\
73.00)\end{array}$ & $\begin{array}{l}63.50(56.50 \\
71.50)\end{array}$ & $0.5919^{\wedge}$ \\
\hline PaO2/FiO2 ratio, Median (Q1,Q3) & $\begin{array}{l}266.75( \\
124.38 \\
421.90)\end{array}$ & $\begin{array}{l}243.25( \\
167.50 \\
380.94)\end{array}$ & $0.9592^{\wedge}$ \\
\hline WBC, Median $(\mathrm{Q} 1, \mathrm{Q} 3)$ & $\begin{array}{l}13.20(9.70 \\
16.50)\end{array}$ & $\begin{array}{l}10.60(8.05 \\
16.30)\end{array}$ & $0.4538^{\wedge}$ \\
\hline INR, Median (Q1,Q3) & $\begin{array}{l}1.12(1.05 \\
1.31)\end{array}$ & $\begin{array}{l}1.24(1.09 \\
1.42)\end{array}$ & $0.2042^{\wedge}$ \\
\hline Platelets count (x 109/L), Median (Q1,Q3) & $\begin{array}{l}223.00( \\
169.00 \\
309.00)\end{array}$ & $\begin{array}{l}214.00( \\
139.50 \\
266.00)\end{array}$ & $0.5408^{\wedge}$ \\
\hline $\begin{array}{l}\text { Activated partial thromboplastin time (aPTT) } \\
\text { (seconds), Median (Q1,Q3) }\end{array}$ & $\begin{array}{l}30.55(27.10 \\
36.50)\end{array}$ & $\begin{array}{l}32.90(26.80 \\
35.20)\end{array}$ & $0.9237^{\wedge}$ \\
\hline Serum creatinine $(\mathrm{mmol} / \mathrm{l})$, Median $(\mathrm{Q} 1, \mathrm{Q} 3)$ & $\begin{array}{l}87.00(65.00 \\
156.00)\end{array}$ & $\begin{array}{l}109.00(58.00 \\
208.00)\end{array}$ & $0.9155^{\wedge}$ \\
\hline BUN, Median (Q1,Q3) & $\begin{array}{l}10.20(6.60 \\
18.95)\end{array}$ & $\begin{array}{l}10.00(5.20 \\
26.50)\end{array}$ & $0.8432^{\wedge}$ \\
\hline $\begin{array}{l}\text { Estimated glomerular filtration rate (eGFR) } \\
(\mathrm{mL} / \mathrm{min} / 1.73 \mathrm{~m} 2) \text {, Median }(\mathrm{Q} 1, \mathrm{Q} 3)\end{array}$ & $\begin{array}{l}78.00(31.00 \\
103.00)\end{array}$ & $\begin{array}{l}47.00(22.00 \\
104.00)\end{array}$ & $0.4401^{\wedge}$ \\
\hline Urine Output (UOP) (mls/kg/hour), Median (Q1,Q3) & $\begin{array}{l}0.31(0.15 \\
0.63)\end{array}$ & $\begin{array}{l}0.28(0.17 \\
0.47)\end{array}$ & $0.6434^{\wedge}$ \\
\hline \multicolumn{4}{|c|}{-Denominator of the percentage is the total number of patients } \\
\hline \multicolumn{4}{|c|}{ *T -Test / ^ Wilcoxon rank sum test is used to calculate the P-value. } \\
\hline \multicolumn{4}{|l|}{${ }^{\wedge \wedge}$ Chi-square test is used to calculate the P-value. } \\
\hline$\star \star$ Fisher Exact test is used to $\mathrm{c}$ & & & \\
\hline
\end{tabular}


Table 2

Outcomes of the between $\mathrm{O}$ and Non-O groups.

\begin{tabular}{|c|c|c|c|c|c|}
\hline & $\begin{array}{l}0 \text { group } \\
(\mathrm{N}=37)\end{array}$ & $\begin{array}{l}\text { Non-0 } \\
\text { group } \\
(\mathrm{N}=44)\end{array}$ & p-value & $\begin{array}{l}\text { OR }(95 \% \mathrm{Cl}) \\
/ \\
\text { Estimates } \\
\text { (SE) }\end{array}$ & $\begin{array}{l}\text { p- } \\
\text { value }\end{array}$ \\
\hline CA-UTI MDR reinfection, $\mathrm{n}(\%)$ & $4(11.1)$ & $2(4.8)$ & $0.4063^{\star \star}$ & $\begin{array}{l}2.12(0.459 \\
, 9.776)\end{array}$ & $0.3365^{\$}$ \\
\hline $\begin{array}{l}\text { CA-UTI Recurrent infection, } n \\
(\%)\end{array}$ & $6(17.1)$ & $14(33.3)$ & $0.0671^{\wedge \wedge}$ & $\begin{array}{l}0.28(0.085 \\
, 0.952)\end{array}$ & $0.0414^{\$}$ \\
\hline CA-UTI Reinfection, n (\%) & $4(11.4)$ & $3(7.1)$ & $0.6954 \star \star$ & $\begin{array}{l}1.47(0.357 \\
, 6.054)\end{array}$ & $0.5928^{\$}$ \\
\hline \multicolumn{6}{|l|}{ Status of CA-UTI, n (\%) } \\
\hline Resistant & $11(29.7)$ & 19 (43.2) & \multirow[t]{2}{*}{$0.4380^{\wedge \wedge}$} & $\begin{array}{l}0.74(0.263 \\
2.055)\end{array}$ & $0.3439 \$$ \\
\hline Sensitive & $21(70.3)$ & $25(56.8)$ & & Ref & \\
\hline \multicolumn{6}{|l|}{$\begin{array}{l}\text { Pattern of CA-UTI Resistant, } n \\
(\%)\end{array}$} \\
\hline Multidrug-Resistant (MDR) & $4(36.4)$ & $15(78.9)$ & \multirow[t]{3}{*}{$0.0330 * \star$} & $\begin{array}{l}0.05(0.003 \\
, 0.752)\end{array}$ & $0.0304^{\$ \$}$ \\
\hline $\begin{array}{l}\text { Extensively Drug-Resistant } \\
\text { (XDR) }\end{array}$ & $6(54.5)$ & $03(15.8)$ & & \multicolumn{2}{|l|}{ Ref } \\
\hline Pandrug-Resistant (PDR) & $1(9.0)$ & $1(5.3)$ & & $\begin{array}{l}0.03(< \\
0.001 \\
, 5.274)\end{array}$ & $0.1844^{\$ \$}$ \\
\hline $\begin{array}{l}\text { Mechanical Ventilation duration } \\
\text { (days), Median }(\mathrm{Q} 1, \mathrm{Q} 3)\end{array}$ & $\begin{array}{l}4.00(0.00 \\
16.00)\end{array}$ & $\begin{array}{l}11.00( \\
0.00, \\
22.00)\end{array}$ & $0.1123^{\wedge}$ & $-0.41(0.066)$ & $<0.001^{\mathrm{s}^{*}}$ \\
\hline $\begin{array}{l}\text { ICU length of stay (LOS), } \\
\text { Median (Q1,Q3) }\end{array}$ & $\begin{array}{l}17.00( \\
7.00 \\
35.00)\end{array}$ & $\begin{array}{l}23.50( \\
12.50 \\
44.50)\end{array}$ & $0.2088^{\wedge}$ & $\begin{array}{l}-0.24 \\
(0.045)\end{array}$ & $<0.001^{\text {\$* }}$ \\
\hline $\begin{array}{l}\text { Hospital length of stay (LOS), } \\
\text { Median (Q1,Q3) }\end{array}$ & $\begin{array}{l}47.00( \\
25.0 \\
102.0)\end{array}$ & $\begin{array}{l}56.00( \\
36.50 \\
129.0)\end{array}$ & $0.2904^{\wedge}$ & $-0.15(0.025)$ & $<0.001^{\text {\$* }}$ \\
\hline ICU mortality, n (\%) & $6(16.2)$ & $12(27.3)$ & 0.2331 & $\begin{array}{l}0.70(0.219 \\
, 2.257)\end{array}$ & $0.5538^{\$}$ \\
\hline $\begin{array}{l}\text {-Denominator of the percentage } \mathrm{i} \\
\text { category. }\end{array}$ & e total $n$ & r of patie & C: Not & Itable, Ref: & erence \\
\hline
\end{tabular}




\begin{tabular}{|c|c|c|c|}
\hline $\begin{array}{l}\text { O group } \\
(N=37)\end{array}$ & $\begin{array}{l}\text { Non-0 } \\
\text { group } \\
(\mathrm{N}=44)\end{array}$ & $\begin{array}{l}\text { OR }(95 \% \mathrm{Cl}) \\
\text { / Estimates } \\
(\mathrm{SE})\end{array}$ & $\begin{array}{l}\text { p- } \\
\text { value }^{\$ * *}\end{array}$ \\
\hline \multicolumn{4}{|l|}{${ }^{\wedge \wedge}$ Chi-square test is used to calculate the P-value. } \\
\hline \multicolumn{4}{|c|}{$\$^{\star}$ Generalized linear model is used to calculate estimates and p-value. } \\
\hline \multicolumn{4}{|c|}{$\$ \$$ Multinomial logistic regression model is used to calculate Odds ratio and p-value. } \\
\hline \multicolumn{4}{|c|}{$\$$ Logistic regression is used to calculate Odds ratio and $\mathrm{p}$-value. } \\
\hline \multicolumn{4}{|c|}{ **Fisher Exact test is used to calculate the P-value. } \\
\hline \multicolumn{4}{|c|}{$\begin{array}{l}\text { \$*The model estimates were adjusted for following prognostic factors body mass index (BMI), } \\
\text { Baseline APACHE II severity score, history of Acute Kidney Injury, status of Previous surgery with } 3 \\
\text { months and status of Previous dialysis within } 3 \text { months. }\end{array}$} \\
\hline
\end{tabular}

\section{Outcomes}

There were 6 patients (54.5\%) with Extensively Drug-Resistant (XDR) followed by 4 (36.4\%) with multidrug-resistant organisms (MDRO) in O blood group. On the other hand, in non-O blood group. 15 (78.9\%) patients had been reported with MDRO followed by $3(15.8 \%)$ with XDR. The odds of experiencing MDRO were $95 \%$ less in O blood group as compared to non-O blood group (adjusted OR: $0.05,95 \% \mathrm{Cl}$ $(0.003,0.752), p=0.0304)$. The odds of getting at least one recurrent infection were $82 \%$ less in patients in $O$ blood group compared with non-O blood group (adjusted OR: $0.28,95 \% \mathrm{Cl}(0.085,0.952), \mathrm{p}=0.0414)$. Table 3 depicts the comparison of baseline severity illness between two blood groups. It was evident from this table that distributions of baseline severity illness scores were very similar between the two blood groups. Table 4 shows the most common CA-UTI organisms in O blood group type patients were $\mathrm{E}$. coli $(61.9 \%)$ followed by Candida species (54.5\%). Whereas, in non-O blood group patients, the common CA-UTI organisms were Candida 10 (45.5\%) followed by E. coli 8 (38.1\%).

Table 3

Comparison baseline Severity between 0 and Non-O groups.

\begin{tabular}{|llll|}
\hline & $\begin{array}{l}\text { O group } \\
(\mathbf{N}=\mathbf{3 7})\end{array}$ & $\begin{array}{l}\text { Non-0 group } \\
\mathbf{( N = 4 4 )}\end{array}$ & p-value \\
\hline APACHE II score, Mean (SD) & $15.95(8.62)$ & $19.31(8.56)$ & $0.0863^{\star}$ \\
\hline NUTRIC Score, Mean (SD) & $4.36(2.02)$ & $4.69(2.33)$ & $0.5103^{\star}$ \\
\hline SOFA score, Median (Q1,Q3) & $6.00(3.00,8.50)$ & $6.00(4.00,9.00)$ & $0.3317^{\wedge}$ \\
\hline *T -Test / ^ Wilcoxon rank sum test is used to calculate the P-value. & \\
\hline
\end{tabular}


Table 4

Most common CA-UTI organisms between $\mathrm{O}$ and Non-O groups.

\begin{tabular}{|lll|}
\hline & $\begin{array}{l}\mathbf{0} \text { group } \\
(\mathbf{N}=\mathbf{3 7})\end{array}$ & $\begin{array}{l}\text { Non-0 group } \\
\mathbf{( N = 4 4 )}\end{array}$ \\
\hline Candida, $\mathrm{n}(\%)$ & $12(54.5)$ & $10(45.5)$ \\
\hline E.Coli, $\mathrm{n}(\%)$ & $13(61.9)$ & $8(38.1)$ \\
\hline Klebsiella, $\mathrm{n}(\%)$ & $12(66.7)$ & $6(33.3)$ \\
\hline Pseudomonas, $\mathrm{n}(\%)$ & $4(40.0)$ & $6(60.0)$ \\
\hline Proteus, $\mathrm{n}(\%)$ & $7(100.0)$ & $0(0.0)$ \\
\hline Acinetobacter, $\mathrm{n}(\%)$ & $1(25.0)$ & $3(75.0)$ \\
\hline Serratia, $\mathrm{n}(\%)$ & $1(50.0)$ & $1(50.0)$ \\
\hline Citrobacter, $\mathrm{n}(\%)$ & $1(50.0)$ & $1(50.0)$ \\
\hline -Denominator of the percentage is the total number of patients in each group. \\
\hline
\end{tabular}

Patients in 0-blood group type had an average ICU length of stay of 17 days as compared to 23.5 days in non-O group type. The ICU length of stay found to be significantly less for patients in 0-group type, (Estimates (STD): -0.24 (0.045), $\mathrm{P}<0.001)$, as well as the hospital length of stay of (Estimates (STD): $-0.15(0.025), \mathrm{P}<0.001)$ compared with non-0 blood group patients. There was a statistically significant association between non-O blood group and recurrence of CA-UTI infection (adjusted OR $0.28,95 \% \mathrm{CI}$ $(0.085,0.952), P=0.0414)$.

Table 2 shows the outcome comparisons between two blood groups after adjusting for the patient's body mass index (BMI), baseline APACHE II score, the status of Acute Kidney Injury within 24 hours of ICU admission, the status of previous surgery and dialysis within 3 months of ICU admission.

\section{Discussion:}

Linking blood types to the occurrence of some diseases and infections is a new science that began to focus on recently (Minardi D. et al. 2011, Ziegler T. et al. 2004, Kinane D. et al. 1982). This connection came from many theories proven the carbohydrate located on RBCs surface plays a crucial role as a receptor for germs, and the attractiveness of these receptors to bacteria, parasites, and viruses varies with the different blood types (Hooton T. et al. 2001, Haylen B. et al. 2009, Hawn T. et al. 2009). Our study is a retrospective cohort investigate the correlation between blood group type and catheter-associated urinary tract infection recurrent, reinfection, and the prevalence of the multidrug-resistant in reinfection cases in CA-UTI among adult critically ill patients as main endpoint. Although, we determine ICU 30 days' mortality, ICU length of stay as asecondary endpoints. 
The prevalence of UTI recurrent episodes are remarkably higher in non-O group types (17.1\% vs. 33.3\%) $(p=0.0414)$, where the reinfection episodes not differ between the two groups $(11.4 \%$ vs. $7.1 \%)(P=$ 0.5928). Our data also reveal that O-blood group types have a lower incidence of multi-drug resistant gram-negative bacteria compared with non-O group types $(P=0.0304)$. A study by Rocha $D$ and colleagues include a total of 307 patients, found that type A blood group patients have a higher predisposition to get urinary tract infections compared with other groups (Rocha D. et al. 2015). Another study by Sheinfeld $\mathrm{J}$ and colleagues observing the correlation between the Lewis blood-group phenotype and recurrent urinary tract infections among women, this study has shown a relationship between recurrent UTI among Lewis blood-group non-secretor (Le $(a+b-))$ and recessive (Le(a-b-)) phenotypes (Sheinfeld J. et al. 1989). Comparatively, optimal antibiotic choice, dosing, and duration directly affects treatment success and improve patients' outcomes (Cotta M. et al. 2015). Therefore, we excluded the patients who received sub-optimal antibiotics doses.

Moreover, O-blood group types patients also have shorter ICU and hospital length of stay (47 days vs. 56 days) and (17 days vs. 23 days) respectively. A prospective cohort study by John $\mathrm{P}$ and colleagues scout about the relation between $\mathrm{ABO}$ blood types with $\mathrm{AKI}$ risk in critically ill patients with trauma or sepsis (Reilly J. et al. 2015). This study shows that patients with blood type A are independently associated with acute kidney injury risk and tend to acquired infections and experience more severe sepsis compared with other blood group types (Reilly J. et al. 2015). On the contrary, this infection tendency and severity could contribute to longer hospital length of stay (Rocha D. et al. 2015, Reilly J. et al. 2015). In the other hand, our study shows no mortality difference between the two groups. Single-center retrospective cohort study enrolled 141 patients with severe burn injuries, shows that patients with blood type 0 have increased mortality and AKI risk (Yao R. et al. 2020).

In our study, the latex rubber catheters were used. Patients with latex allergy were switched to silicone catheters. Also, patients who are expected to stay on urinary catheter for a long time they switched to silicone catheters. Urinary catheters are essentially available in three types of materials: silicone, latex rubber and polyvinyl chloride or polyvinyl chloride (PVC) (Moola S. et al. 2010). The most frequently used in medical practice (Tamura N. et al. 2003, Hosseinpour M. et al. 2014). More often, latex rubber catheters are cheap and flexible but carry a lot of concerns such as hypersensitivity reactions, also it is associated with higher urinary catheter infections (Moola S. et al. 2010, Tamura N. et al. 2003, Hosseinpour M. et al. 2014). Also, in our study we did not correlate the latex rubber catheters with the incidence of urinary tract infections either the first episode or recurrent as it's prone to cause infections.

Lack of large and well-conducted studies connecting the prevalence of infections, reinfection, and infection severity with human papulation blood group types is one of the serious limitations for this study. Although the patients' data collected retrospectively which is give us no chance to interfere with the patient's therapeutic plane or even observing the patients directly. However, our research population is all critically ill patients, and the length of ICU stay, MDRO incidence or reinfection could have affected by many other factors not specifically related to blood group types. Conversely, our study is the first of its kind to examine the relationship between CA-UTI recurrent, reinfection, and MDRO prevalence and blood 
group type among ICU patients. Further researches with a larger sample size should be done to investigate the relationship between blood groups and infections tendency.

\section{Abbreviations}

Infectious Diseases Society of America (IDSA), Length of Stay (LOS), red blood cells (RBCs), multidrug resistant organism (MDRO), Sequential Organ Failure Assessment (SOFA), Acute Physiology And Chronic Health Evaluation II (APACHE II).

\section{Declarations}

\section{Ethical consideration}

The study was approved by King Abdullah International Medical Research Center Institutional Review Board, Riyadh, Saudi Arabia. Participants' confidentiality was strictly observed throughout the study by using the anonymous unique serial numbers for each subject and restricting data only to the investigators. Informed consent was not required due to the research's method as per the policy of the governmental and local research center. The datasets used and/or analyzed during the current study are available from the corresponding author on reasonable request.

\section{Author contributions}

All authors contributed to data collections, analysis, drafted, revised and approved the final version of the manuscript.

\section{Compliance with Ethical standards:}

Funding: None

Disclosure: No author has a conflict of interest in this study.

\section{Availability of data and material:}

Data are available on request due to privacy and ethical restrictions.

\section{References}

1-Al Sulaiman K, Al Aamer K, Al Harthi A, et al. (2020) 'Comparison between esomeprazole 20 mg Vs 40 mg as stress ulcer prophylaxis (SUP) in critically ill patients: A retrospective cohort study', Pharmacol Res Perspect, 8(4).

2-Annette epp, annicklarochelle (2010) 'Recurrent urinary tract infection', Journal of Obstetric Gynaecology, 32(11), pp. 1082-1090. 
3- Chant C, Smith O, Marshall J, Friedrich J (2011) ' Relationship of catheter-associated urinary tract infection to mortality and length of stay in critically ill patients: A systematic review and meta-analysis of observational studies.', Crit Care Med, 39(5), pp. 1167-1173.

4- Cotta M, Roberts J, Lipman J (2015) 'Antibiotic dose optimization in critically ill patients', Medicina Intensiva, 39(9), pp. 563-572.

5- Gould CV, Umscheid CA, Agarwal RK, et al. (2010) 'Guideline for prevention of catheter-associated urinary tract infections ', Infect Control Hosp Epidemiol , (31), pp. 319.

6- Haylen B, Lee J, Husselbee S, Law M, Zhou J (2009) 'Recurrent urinary tract infections in women with symptoms of pelvic floor dysfunction', Int Urogynecol J, 20(7), pp. 837-842.

7-Hawn T, Scholes D, Li S et al. (2009) ' Toll-Like Receptor Polymorphisms and Susceptibility to Urinary Tract Infections in Adult Women', PLoS ONE, 4(6), pp. 5990.

8- Hooton T. (2001) 'Recurrent urinary tract infection in women. ', Int J Antimicrob Agents, 17(4), pp. 259268.

9- Hooton TM, Bradley SF, Cardenas DD, et al. (2010) ' Diagnosis, prevention, and treatment of catheterassociated urinary tract infection in adults: 2009 International Clinical Practice Guidelines from the Infectious Diseases Society of America', Clin Infect Dis, 50(625),

10- Hosseinpour M, Noori S, Pourfakharan M, Amir-Beigi M, Ehteram H, Hamsayeh M. (2014) 'Safety of latex urinary catheters for the short time drainage. ', Urol Ann, 6(3), pp. 198.

11- Johnson, J.R. (2014) ' Virulence factors in Escherichia coli urinary tract infection', Clinical Microbiology Reviews, 4(1), pp. 80-128.

12- Kinane, D.F., Blackwell, C.C., Brettle, R.P., Weir, D.M., Winstanley, F.P. and Elton, R.A. (1982) ' ABO blood group, secretor state, and susceptibility to recurrent urinary tract infection in women', Br Med J (Clin Res Ed), 285(6334), pp. 7-9.

13- Kunin CM, McCormack RC (1966) 'Prevention of catheter-induced urinary-tract infections by sterile closed drainage', N Engl J Med, 274(1155), 14- Leuck AM, Wright D, Ellingson L, et al. (2012) 'Complications of Foley catheters-is infection the greatest risk?', J Urol, 187(1662), 15- Liumbruno GM, Franchini M (2013) 'Beyond immunohaematology: the role of the ABO blood group in human diseases. Blood Transfus. ', Blood Transfus, 11(4), pp. 491-499.

16- Lo E, Nicolle L, Coffin S et al. (2014) 'Strategies to Prevent Catheter-Associated Urinary Tract Infections in Acute Care Hospitals', Infection Control \& Hospital Epidemiology. , 35(32), pp. 47.

17 - Mohandas, N. and Narla, A. (2005) 'Blood group antigens in health and disease', Current opinion in hematology, 12(2), pp. 135-140. 
18- Moola S, Konno R. A (2010) ' A systematic review of the management of short-term indwelling urethral catheters to prevent urinary tract infections', JBI Database System Rev Implement Rep, 8(17), pp. 695-729.

19- Minardi D, d'Anzeo, Cantoro, Conti, Muzzonigro (2011) ' Urinary tract infections in women: etiology and treatment options', Int J Gen Med., 333. 20- Nicolle, L.E. (2014) 'Catheter associated urinary tract infections. ', Antimicrob Resist Infect Control , 3(23),

21- Peter d'adamo (2015) 'Blood group, secretor status and the microbiome', Environmental Genomics, 22- Platt R, Polk BF, Murdock B, Rosner B (1986) ' Risk factors for nosocomial urinary tract infection', Am J Epidemiol , 124(977)

23- Puri J, Mishra B, Mal A et al. (2002) 'Catheter Associated Urinary Tract Infections in Neurology and Neurosurgical Units', Journal of Infection, 44(3), pp. 171-175.

24- Reid, M.E. and Mohandas, N. (2004) 'Red blood cell blood group antigens: structure and function', In Seminars in Hematology , 41(2), pp. 93-117.

25- Reilly J, Anderson B, Mangalmurti N et al. (2015) 'The ABO Histo-Blood Group and AKI in Critically III Patients with Trauma or Sepsis.', Clinical Journal of the American Society of Nephrology, 10(11), pp. 1911-1920.

26- Rocha D, Silva A, et al. (2015) 'Urinary tract infections and blood groups: Do they relate? ', Int. Inv. J. Med. Med. Sci. , 2(5), pp. 66-72.

27- Schoolnik, G.K. (1989) 'How Escherichia coli infects the urinary tract', New England Journal of Medicine, 320, pp. 804-805. 28- Sigmon, J.M. (1992) 'Basic principles of the ABO and Rh blood group systems for hemapheresis practitioners', Journal of Clinical Apheresis, 7(3), pp. 158-162.

29- Stapleton, A., Nudelman, E., Clausen, H., Hakomori, S.I. and Stamm, W.E. (1992) 'Binding of uropathogenic Escherichia coli R45 to glycolipids extracted from vaginal epithelial cells is dependent on histo-blood group secretor status', The Journal of Clinical Investigation, 90(3), pp. 965-972.

30- Sheinfeld J, Schaeffer A, Cordon-Cardo C, Rogatko A, Fair W (1989) 'Association of the Lewis BloodGroup Phenotype with Recurrent Urinary Tract Infections in Women', New England Journal of Medicine. , 320(12), pp. 773-777.

31- Tamura N, Gasparetto A, Svidzinski T (2003) ' Evaluation of the Adherence of Candida Species to Urinary Catheters', Mycopathologia, 156(4), pp. 269-272.

32- Warren JW, Muncie HL Jr, Hall-Craggs M. (1988) 'Acute pyelonephritis associated with bacteriuria during long-term catheterization: a prospective clinicopathological study', J Infect Dis, 158(1341) 
33- Weber DJ, Sickbert-Bennett EE, Gould CV, Brown VM, Huslage K, Rutala WA. (2011) 'Incidence of catheter-associated and non-catheter-associated urinary tract infections in a healthcare system', Infect Control Hosp Epidemiol, 32, pp. 822-823.

34- Weiner LM, Webb AK, Limbago B, et al. (2016) ' Antimicrobial-Resistant Pathogens Associated With Healthcare-Associated Infections: Summary of Data Reported to the National Healthcare Safety Network at the Centers for Disease Control and Prevention, 2011-2014', Infect Control Hosp Epidemiol , 37(1288).

35- Yao R, Hou W, Shen T et al. (2020) 'The Impact of Blood Type O on Major Outcomes in Patients With Severe Burns', Journal of Burn Care \& Research. 36- Ziegler T, Jacobsohn N, Fünfstück R. (2004) 'Correlation between blood group phenotype and virulence properties of Escherichia coli in patients with chronic urinary tract infection.', Int J Antimicrob Agents, 24, pp. 70-75. 